\title{
Nonspecific, concentration-dependent stimulation and repression of mammalian gene expression by small interfering RNAs (siRNAs)
}

\author{
STEPHAN P. PERSENGIEV, XIAOCHUN ZHU, and MICHAEL R. GREEN
}

Howard Hughes Medical Institute, Programs in Gene Function and Expression and Molecular Medicine, University of Massachusetts Medical School, Worcester, Massachusetts 01605, USA

\begin{abstract}
RNA interference is an evolutionarily conserved process in which expression of a specific gene is post-transcriptionally inhibited by a small interfering RNA (siRNA), which recognizes a complementary mRNA and induces its degradation. Currently, RNA interference is being used extensively to inhibit expression of specific genes for experimental and therapeutic purposes. For applications in mammalian cells, siRNAs are designed to be $<\sim 30$ base pairs to avoid nonspecific effects that arise from inducing the cellular double-stranded RNA (dsRNA)-dependent protein kinase (PKR) response. Here we perform expression profiling in mammalian tissue-culture cells treated under standard conditions with conventional 21-bp siRNAs and find, unexpectedly, that $>1000$ genes involved in diverse cellular functions are nonspecifically stimulated or repressed. The effects on gene expression are dependent upon siRNA concentration and are stable throughout the course of siRNA treatment. Our results can be explained by previous studies showing that dsRNAs can affect multiple signaling and transcription pathways in addition to PKR. The potential for this widespread, nonspecific effect on mammalian gene expression must be carefully considered in the design of siRNA experiments and therapeutic applications.
\end{abstract}

Keywords: RNA interference; siRNA; interferon response; PKR response

\section{INTRODUCTION}

RNA interference (RNAi) is an evolutionarily conserved process of sequence-specific, post-transcriptional gene silencing that uses double-stranded RNA (dsRNA) as the signal to trigger the degradation of homologous mRNA (for review, see Fire 1999; Sharp 2001; Hannon 2002; Plasterk 2002; Zamore 2002). The mechanism by which dsRNA induces gene silencing involves a two-step process. First, long dsRNAs are recognized by the ribonuclease III-like enzyme Dicer, which cleaves the dsRNA into smaller RNAs of 21-23 nt. These small interfering RNAs (siRNAs) are then incorporated into a multicomponent nuclease complex known as the RNA-induced silencing complex (RISC), which recognizes and targets cognate mRNAs for destruction.

Reprint requests to: Michael R. Green, Howard Hughes Medical Institute, Programs in Gene Function and Expression and Molecular Medicine, University of Massachusetts Medical School, Worcester, MA 01605, USA; e-mail: michael.green@umassmed.edu; fax: (508) 856-5473.

Article and publication are at http://www.rnajournal.org/cgi/doi/ $10.1261 /$ rna5160904.
RNAi has proven to be an effective tool for studying gene function in numerous organisms, including Caenorhabditis elegans, Drosophila, and plants (Hannon 2002). In mammalian cells, however, the use of RNAi for targeted gene silencing has been limited due to nonspecific effects induced by long dsRNAs, which result in interferon (IFN) activation and induction of the cellular dsRNA-dependent protein kinase (PKR) response. Therefore, for applications in mammalian cells, siRNAs are designed to be $<\sim 30$ bp to circumvent the PKR response and avoid nonspecific effects on gene silencing (see, for example, Caplen et al. 2001; Elbashir et al. 2001).

Currently, siRNAs are being used extensively in mammalian cells to inhibit expression of specific genes for experimental and therapeutic purposes. A critical assumption of this approach is that the siRNA will selectively inhibit the complementary gene. Here, by using expression profiling, we show that conventional siRNAs can in a concentrationdependent manner nonspecifically stimulate or repress expression of $>1000$ genes with protein products that are involved in diverse cellular functions. 


\section{RESULTS AND DISCUSSION}

\section{Expression profiling reveals nonspecific effects on mammalian gene expression by siRNAs}

To identify targets of transcription factors, we had been performing expression profiling after siRNA treatment of mammalian tissue-culture cells. As a nonspecific control in these studies, we used a well-characterized siRNA directed against a luciferase reporter gene (Elbashir et al. 2001; Schwarz et al. 2002). This siRNA efficiently silences luciferase expression at a concentration of $1 \mathrm{nM}$ (Schwarz et al. 2002). Unexpectedly, after transfection with $200 \mathrm{~nm}$ luciferase siRNA under standard conditions, we found that of the 33,000 genes represented on an Affymetrix U133 chip, expression of 1154 genes increased and expression of 689 genes decreased by $\geq 2.5$-fold compared with untreated cells. Genes with expression that was altered by luciferase siRNA treatment encoded proteins involved in diverse cellular activities, including cell signaling, cytoskeletal organization, gene expression, metabolism, and cell adhesion (Table 1).

Twelve genes with expression that was either increased or decreased by luciferase siRNA treatment were randomly selected for further characterization. To confirm the results of the microarray experiment, we performed RT-PCR analysis. Figure 1A shows that expression of all six of the genes up-regulated in the microarray analysis were increased to varying extents by treatment with the luciferase siRNA. Likewise, expression of all six of the down-regulated genes in the microarray analysis were decreased to varying extents after treatment with the luciferase siRNA. Consistent with the microarray analysis, expression of GAPDH was unaffected. Significantly, treatment of cells with the transfection reagent (Oligofectamine) alone did not affect expression of any of the 12 genes analyzed, indicating the effect is attributable to the siRNA. We presume this is also the case for the other genes with expression that was affected in the microarray analysis.

The luciferase siRNA used in the above experiments lacks significant sequence similarity to any human gene. It therefore seemed likely that the effects on gene expression we observed were independent of the specific siRNA sequence. To confirm this prediction, we analyzed expression of several genes after treatment with a randomized nonspecific control siRNA, which again lacks significant similarity to any human gene. The results of Figure $1 \mathrm{~B}$ show that the luciferase siRNA and the nonspecific siRNA had comparable effects on all 12 genes analyzed.

\section{siRNA treatment affects gene expression in a concentration-dependent manner}

We sought to determine whether the nonspecific effects on gene expression were dependent upon siRNA concentra- tion. We therefore analyzed the expression of a subset of genes at siRNA concentrations ranging from 0 to $200 \mathrm{nM}$. The results of Figure 2A show, as observed above, that at $200 \mathrm{nM}$ luciferase siRNA, expression of FGG, IGFBP5, and $P C D H 10$ were increased, whereas expression of $\mathrm{CDH} 5$ and Histone $\mathrm{H} 3 \mathrm{H}$ were reduced. At $100 \mathrm{~nm}$ luciferase siRNA, expression of $F G G$, IGFBP5, PCDH10, and $C D H 5$ were still significantly affected and expression of Histone $\mathrm{H} 3 \mathrm{H}$ was affected modestly. When the concentration of luciferase siRNA was reduced to $50 \mathrm{nM}$, expression of IGBP5, CDH5, and Histone $\mathrm{H} 3 \mathrm{H}$ remained modestly affected. Further reduction to $25 \mathrm{nM}$ still affected $\mathrm{CDH} 5$ and Histone $\mathrm{H} 3 \mathrm{H}$ expression, whereas IGBP5 expression was near normal. Thus, the nonspecific effects on gene expression are dependent upon siRNA concentration in a gene-specific manner.

\section{Kinetics of altered gene expression}

We next analyzed the time-course of altered expression of several genes after siRNA treatment. The results of Figure 2B show that for FGG, IGFBP5, PDK1, and PCDH10, a significant increase in expression was first detected 12 to 24 $\mathrm{h}$ after siRNA treatment and remained constant throughout the remainder of the 72-h time-course. For ZFP36L2 and $P C D H G C 3$, a decrease in expression was first observed $24 \mathrm{~h}$ after siRNA treatment and was maintained, whereas a decrease in expression of TNFSF10 and Histone H3H first occurred $48 \mathrm{~h}$ after siRNA treatment. Thus, the nonspecific effects on gene expression induced by siRNAs are not transient and, once initiated, are sustained throughout the course of siRNA treatment.

\section{siRNAs, long dsRNAs, and IFN affect overlapping pathways}

The nonspecific effects we observed by using siRNAs raise the possibility that dsRNAs can affect gene expression through pathways other than PKR. Of particular significance, polyI.polyC, a long dsRNA homopolymer, can still activate expression of specific genes in knockout mice lacking both copies of the PKR gene (Yang et al. 1995). This result is consistent with reports that dsRNA can activate several protein kinases such as p38, JNK2, and IKK (Kumar et al. 1994; Chu et al. 1999; Williams 1999) in addition to PKR. Induction of these signaling pathways can alter gene expression by regulating the activity of transcription factors such as NF-кB, IRF-3, and ATF-1 (Williams 1999). Because siRNAs do not trigger the PKR response, the most likely explanation for the nonspecific effects on gene expression that we have observed is that siRNAs can affect gene expression through one of these other pathways. As an initial investigation of the pathway(s) affected by siRNAs, we compared the results of our expression profiling analysis with those obtained after treatment with type 1 IFN (Der et al. 1998) or polyI.polyC in cells lacking the type I IFN locus 
TABLE 1. List of selected genes with expression that was either increased or decreased by luciferase siRNA treatment

\begin{tabular}{|c|c|c|c|}
\hline Name and biological function & Acc. no. & Gene product & Fold increase \\
\hline \multicolumn{4}{|l|}{ Stimulated genes } \\
\hline \multicolumn{4}{|l|}{ Cytokine signaling } \\
\hline FGG & NM 000509 & fibrinogen, gamma polypeptide & 5.7 \\
\hline HFL1 & X 56210 & $\mathrm{H}$ factor (complement)-like 1 & 5.4 \\
\hline RAP2B & NM 002886 & member of RAS oncogene family & 4.9 \\
\hline TRG@ & M 16768 & $\mathrm{~T}$ cell receptor gamma locus & 4.2 \\
\hline CCL23 & U 58913 & chemokine (C-C motif) ligand 23 & 4.0 \\
\hline ISG20 & NM 002201 & interferon stimulated gene $20 \mathrm{kD}$ & 3.5 \\
\hline CXCL14 & NM 004887 & chemokine (C-X-C motif) ligand 14 & 3.3 \\
\hline CCL3 & NM 002983 & chemokine (C-C motif) ligand 3 & 2.9 \\
\hline IRF4 & U 52683 & interferon regulatory factor 4 & 2.9 \\
\hline FGL1 & NM 004467 & fibrinogen-like 1 & 2.8 \\
\hline IL5RA & M 96651 & interleukin 5 receptor, $\alpha$ & 2.6 \\
\hline \multicolumn{4}{|l|}{ Cytoskeletal organization } \\
\hline LAMA4 & U 77706 & laminin, $\alpha 4$ & 4.4 \\
\hline BMP2 & NM 001200 & bone morphogenetic protein 2 & 3.0 \\
\hline GOLGA6 & NM 018652 & golgin subfamily a, member 6 & 3.0 \\
\hline COL15A1 & NM 001855 & collagen, type $X V, \alpha 1$ & 2.7 \\
\hline COL16A1 & NM 001856 & collagen, type XVI, $\alpha 1$ & 2.7 \\
\hline \multicolumn{4}{|l|}{ Apoptosis } \\
\hline REPRIMO & NM 019845 & p53 induced G2 arrest mediator & 3.8 \\
\hline \multicolumn{4}{|c|}{ Extracellular matrix/cell adhesion } \\
\hline IGFBP5 & AW 007532 & insulin-like growth factor binding protein 5 & 4.8 \\
\hline EDN2 & NM 001956 & endothelin 2 & 4.6 \\
\hline $\mathrm{CDH} 13$ & NM 001257 & cadherin 13 & 4.2 \\
\hline MRC1 & NM 002438 & mannose receptor, $\mathrm{C}$ type 1 & 3.9 \\
\hline SEPP1 & NM 005410 & selenoprotein $\mathrm{P}$, plasma, 1 & 3.8 \\
\hline FGF13 & NM 004114 & fibroblast growth factor 13 & 3.6 \\
\hline IGF1 & M 37484 & insulin-like growth factor 1 & 3.0 \\
\hline \multicolumn{4}{|l|}{ Metabolism } \\
\hline PDK1 & NM 002610 & pyruvate dehydrogenase kinase, isoenzyme 1 & 4.1 \\
\hline HPD & NM 002150 & 4-hydroxyphenylpyruvate dioxygenase & 3.6 \\
\hline ARHU & NM 021205 & ras homolog gene family, member $U$ & 3.4 \\
\hline NDUFB7 & M 33374 & NADH dehydrogenase 1 beta subcomplex, 7 & 3.2 \\
\hline DNMT3L & NM 013369 & DNA (cytosine-5)-methyltransferase 3-like & 3.1 \\
\hline \multicolumn{4}{|l|}{ Other genes } \\
\hline CGI-60 & NM 016008 & CGI-60 protein & 4.1 \\
\hline ZNF135 & NM 003436 & zinc finger protein 135 & 3.0 \\
\hline FKBP8 & L 37033 & FK-506 binding protein 8 & 2.8 \\
\hline MAGEA1 & NM 004988 & melanoma antigen, family $\mathrm{A}, 1$ & 2.8 \\
\hline \multicolumn{4}{|l|}{ Repressed genes } \\
\hline \multicolumn{4}{|l|}{ RNA synthesis } \\
\hline $18 \mathrm{~S}$ rRNA & M 10098 & $18 \mathrm{~S}$ ribosomal RNA & 3.1 \\
\hline $28 S$ rRNA & M 11167 & $28 \mathrm{~S}$ ribosomal RNA & 2.8 \\
\hline \multicolumn{4}{|l|}{ Metabolism } \\
\hline ACOX2 & NM 003500 & acyl-Coenzyme A oxidase 2 & 4.7 \\
\hline ALPP & NM 001632 & alkaline phosphatase, placental & 4.2 \\
\hline $\mathrm{RODH}$ & NM 003725 & 3-hydroxysteroid epimerase & 4.2 \\
\hline MAOA & NM 000240 & monoamino oxidase $\mathrm{A}$ & 3.8 \\
\hline GAD2 & M 81882 & glutamate decarboxylase 2 & 3.4 \\
\hline DUSP6 & AB 013382 & dual specificity phosphatase 6 & 3.1 \\
\hline
\end{tabular}

(Table 2; Geiss et al. 2001). Interestingly, most of the genes were affected by two but not all three of the inducing agents. As expected, a number of genes were affected by treatment with IFN and long dsRNAs but not by siRNAs. This is presumably because IFN and long dsRNAs induce expression of these genes through the PKR pathway, which is not activated by siRNAs. Consistent with this conclusion, RT-PCR analysis revealed that several genes with expression that is induced by dsRNA, IFN $\beta$, and $2^{\prime}-5^{\prime}$ oligoadenylate synthetase (OAS), or by IFN, myxovirus-resistance-1 (MXA), and IFN-stimulated gene 54 (ISG-54), were unaffected by siRNA treatment (data not shown). Thus, the 
TABLE 1. Continued

\begin{tabular}{|c|c|c|c|}
\hline Name and biological function & Acc. no. & Gene product & Fold increase \\
\hline \multicolumn{4}{|l|}{ Chromosome organization } \\
\hline HIST1H2AG & NM 021064 & histone 1, H2ag & 3.5 \\
\hline HIST1H2AE & NM 021052 & histone 1, H2ae & 3.4 \\
\hline $\mathrm{H} 3 \mathrm{FH}$ & NM 003534 & histone $\mathrm{H} 3$ family, member $\mathrm{H}$ & 3.1 \\
\hline H3FL & NM 003537 & histone $\mathrm{H} 3$ family, member $\mathrm{L}$ & 2.9 \\
\hline \multicolumn{4}{|c|}{ Extracellular matrix/cell adhesion } \\
\hline $\mathrm{CDH} 5$ & NM 001795 & cadherin 5 , type 2 & 4.1 \\
\hline CD5 & NM 014207 & CD5 antigen (p56-62) & 3.3 \\
\hline PCDHGC3 & L 11372 & protocadherin gamma subfamily $\mathrm{C}, 3$ & 3.1 \\
\hline CD1D & NM 001766 & CD1D antigen, $d$ polypeptide & 2.5 \\
\hline CD38 & NM 001775 & CD38 antigen $(p 45)$ & 2.5 \\
\hline PCDH11X & NM 014522 & protocadherin $11 \mathrm{X}$-linked & 2.5 \\
\hline \multicolumn{4}{|l|}{ Cell signaling } \\
\hline TNFSF10 & NM 003810 & tumor necrosis factor superfamily, member 10 & 4.8 \\
\hline IL11 & NM 000641 & interleukin 11 & 4.5 \\
\hline SLC2A6 & NM 017585 & solute carrier family 2 , member 6 & 4.5 \\
\hline ZFP36L2 & NM 006887 & zinc finger protein $36, \mathrm{C} 3 \mathrm{H}$ type-like 2 & 4.4 \\
\hline INHBB & NM 002193 & inhibin $\beta$ B & 3.8 \\
\hline HBP17 & NM 005130 & heparin-binding growth factor binding protein & 3.5 \\
\hline RARRES1 & NM 002888 & retinoic acid receptor responder 1 & 3.0 \\
\hline FGF18 & NM 003862 & fibroblast growth factor 18 & 2.8 \\
\hline FGFR4 & AF 202063 & fibroblast growth factor receptor 4 & 2.8 \\
\hline SLC21A12 & NM 016354 & solute carrier family 21 , member 12 & 2.8 \\
\hline SSI1 & U 88326 & suppressor of cytokine signaling 1 & 2.8 \\
\hline IL7 & NM 000880 & interleukin 7 & 2.5 \\
\hline \multicolumn{4}{|l|}{ Transcription } \\
\hline $\mathrm{EHF}$ & NM 012153 & ets homologous factor & 3.6 \\
\hline ELF4 & NM 001421 & E74-like factor 4 & 3.3 \\
\hline GLI2 & NM 030379 & GLI-Kruppel family member & 3.1 \\
\hline SHOX2 & AF 022654 & short stature homeobox 2 & 2.9 \\
\hline DLX2 & NM 004405 & distal-less homeobox 2 & 2.8 \\
\hline PITX2 & NM 000325 & paired-like homeodomain transcription factor 2 & 2.8 \\
\hline HOXC5 & NM 018953 & homeobox $\mathrm{C} 5$ & 2.5 \\
\hline \multicolumn{4}{|l|}{ Other genes } \\
\hline CDC14A & NM 003672 & cell division cycle 14 homolog A & 6.4 \\
\hline PSCA & NM 005672 & prostate stem cell antigen & 5.5 \\
\hline SERPINB4 & AB 046400 & serine proteinase inhibitor, clade B, member 4 & 4.3 \\
\hline MDA5 & NM 022168 & melanoma differentiation associated protein 5 & 4.1 \\
\hline HSPA1A & NM 005345 & heat-shock $70-k D$ protein $1 \mathrm{~A}$ & 3.8 \\
\hline DPT & NM 001937 & dermatopontin & 3.1 \\
\hline
\end{tabular}

pathways affected by IFN, long dsRNAs, and siRNAs appear to be overlapping but nonidentical.

In this report, we have found that in addition to the well-known ability of siRNAs to silence specific genes, there is also a widespread nonspecific effect on mammalian gene expression. Interestingly, expression of some genes was increased, whereas others were reduced. These nonspecific effects must be considered in the design of controls for siRNA-mediated loss-of-function experiments.

Previous studies examining siRNA specificity have generally monitored expression of only a few genes and probably would not have detected the nonspecific effects described here. However, several recent reports have used expression profiling to reveal nonspecific effects on human gene expression by siRNAs (Jackson et al. 2003; Semizarov et al. 2003) or short hairpin RNAs (shRNAs; Bridge et al.
2003). Below we discuss the relationship and implications of our results and those in these related studies.

What is the mechanism(s) by which siRNAs induce nonspecific effects on gene expression? Jackson et al. (2003) attributed the nonspecific effects they observed to off-target gene regulation, in which the expression of nontarget genes are suppressed due to cross-hybridization of transcripts containing regions of partial homology with the siRNA sequence. The effects we observed, however, cannot be explained by off-target regulation because the siRNAs used in our experiments lacked significant sequence similarity to any human gene. Moreover, for all of the genes tested, expression was affected by two siRNAs (luciferase and nonspecific) with sequences that are completely unrelated.

Bridge et al. (2003) reported that shRNAs can affect the expression of many genes, including several IFN targets, 
A
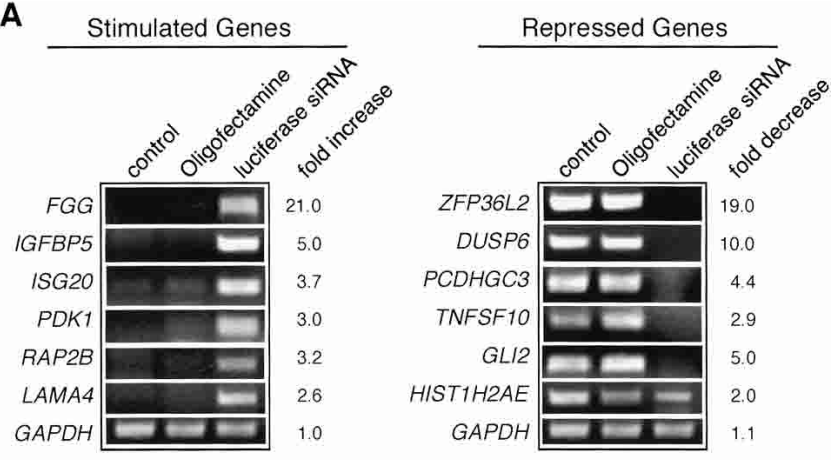

B

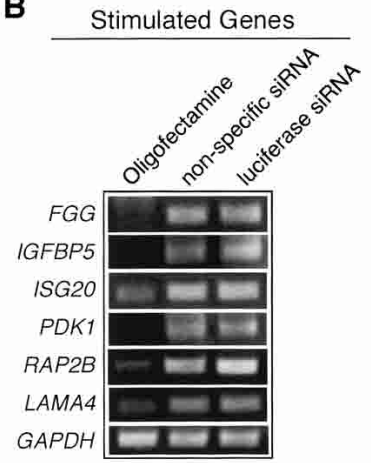

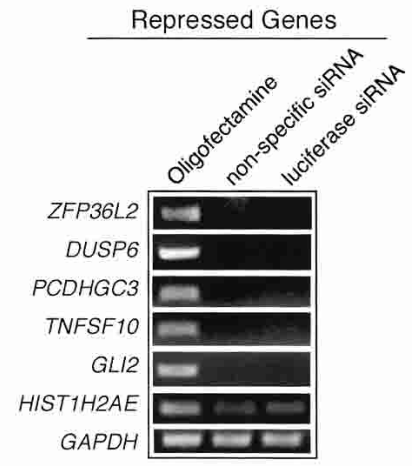

FIGURE 1. Analysis of siRNA-induced alterations in gene expression by RT-PCR. (A) Representative set of up-regulated genes (left) or down-regulated genes (right) after treatment of HeLa cells with transfection reagent (Oligofectamine) alone or with luciferase siRNA. Untreated HeLa cells were used as a control. Fold differences in expression as measured by RT-PCR is indicated on the right. (B) siRNAinduced alteration in gene expression is independent of siRNA sequence. Comparison of luciferase siRNA and a random nonspecific siRNA on the expression of a selected set of stimulated genes (left) or repressed genes (right). Oligofectamine-treated cells were used as a control.

centration. Semizarov et al. (2003) reported nonspecific effects that occurred at an siRNA concentration of $100 \mathrm{nM}$ but not at $20 \mathrm{nM}$. Thus, we suspect that the nonspecific effects reported by Semizarov et al. (2003) are related to our results. However, for several reasons it is not yet clear that the basis for altered gene expression in our study is identical to that of Semizarov et al. (2003). Specifically, unlike our study, Semizarov et al. used only microarray analysis to study expression, did not test whether different unrelated siRNAs comparably altered the expression of specific genes, and did not analyze the kinetics of altered expression. Finally, Semizarov et al. (2003) did not report genes with expression that was nonspecifically reduced by siRNAs in a concentration-dependent fashion.

Gene silencing experiments in mammalian cells have used siRNAs at varying concentrations, typically ranging from $20 \mathrm{nM}$ (Semizarov et al. 2003) to $200 \mathrm{nM}$ (Wu et al. 2003). Many published studies report using siRNAs at 100 $\mathrm{nM}$, a concentration that is also suggested by manufacturers of siRNAs and siRNA-related products. Significantly, 100 nM siRNA is a concentration at which we found nonspecific effects occur. Unfortunately, however, lowering the concentration of a particular siRNA $<100 \mathrm{nM}$ can reduce silencing efficiency. These considerations underscore the importance of determining the rules for siRNA design so that optimal silencing efficiency can be achieved at minimal siRNA concentrations to avoid nonspecific effects.

\section{MATERIALS AND METHODS}

\section{SiRNA preparation}

The siRNAs were chemically synthesized by the UMass CFAR ( enter for AIDS Research) Molecular Biology Core using 2'- and therefore suggested that shRNAs induce an IFN response. Because shRNAs are processed to siRNAs in the cell, these observations raised the possibility that siRNAs might also induce an IFN response. However, a comparison of genes affected by siRNAs and IFN (Table 2) revealed that siRNAs affect pathways that are overlapping but not identical to those regulated by IFN. Thus, siRNAs do not trigger a true IFN response. More importantly, Bridge et al. (2003) reported that the nonspecific effects occurred with an shRNA expressed from an RNA polymerase III promoter but not with a synthetic siRNA. In contrast, the nonspecific effects we observed occurred with synthetic siRNAs.

A characteristic feature of the nonspecific effects on gene expression we observed was dependence on siRNA con-
A

A
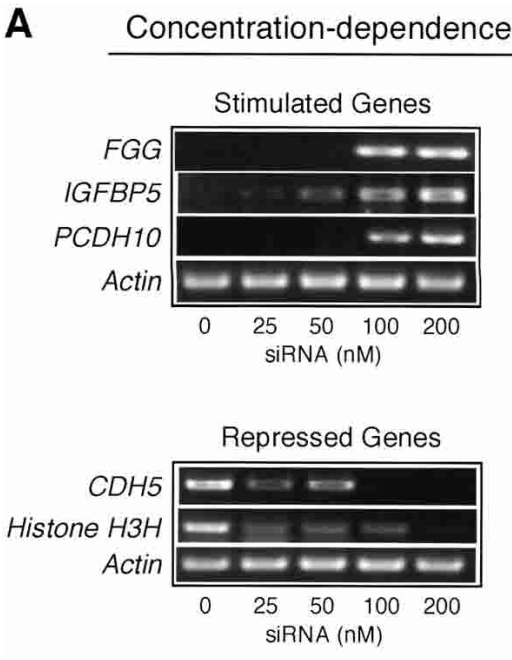

B
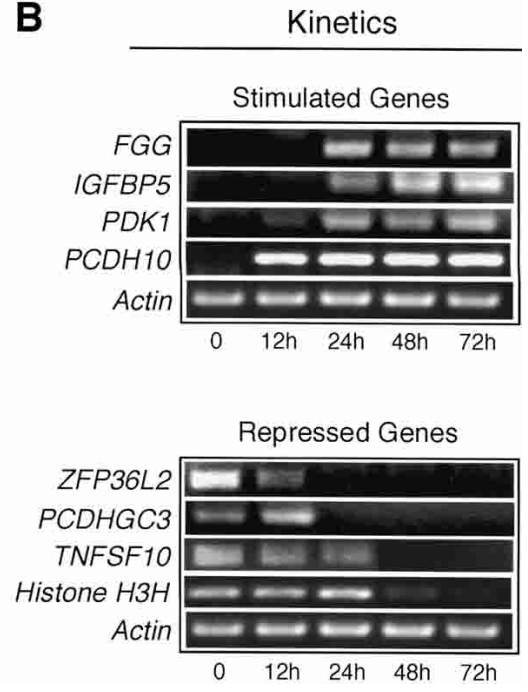

FIGURE 2. Concentration-dependence and kinetics of siRNA-induced alteration in gene expression. (A) Concentration-dependence. Comparison of varying concentrations of luciferase siRNA on the expression of a selected set of genes. (B) Kinetics. Time-course analysis by RT-PCR of selected genes with expression that increased or decreased after luciferase siRNA treatment. 
TABLE 2. Comparison of selected genes affected by siRNA, poly(I):poly(C), and interferon type 1

\begin{tabular}{|c|c|c|c|}
\hline Gene description & siRNA & $\begin{array}{c}\text { long } \\
\text { dsRNA }\end{array}$ & IFN- $\alpha / \beta$ \\
\hline Guanylate binding protein 1, interferon inducible (GBP1) & $\bullet$ & $\bullet$ & $\bullet$ \\
\hline $\begin{array}{l}\text { Cell division cycle } 14 \text { homolog A (CDC14A) } \\
\text { Chemokine (C-C motif) ligand } 2 \text { (CCL2) } \\
\text { Fibroblast growth factor } 2 \text { (FGF2) } \\
\text { Proteoglycan 1, secretory granule (PRG1) }\end{array}$ & $\stackrel{\bullet}{\bullet}$ & 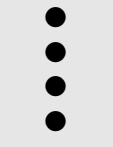 & \\
\hline $\begin{array}{l}\text { Caspase } 8 \text { (CASP8) } \\
\text { CCAAT/enhancer binding protein delta (C/EBPD) } \\
\text { Chemokine (C-X-C motif) ligand } 11(\mathrm{CXCL} 11)^{\mathrm{a}} \\
\text { Collagen, type XVI, alpha } 1(\mathrm{COL} 16 \mathrm{~A} 1) \\
\text { Glucose monophosphate reductase (GMPR) } \\
\text { Interferon stimulated gene 20kDa (ISG20) } \\
\text { Zinc finger protein } 36, \mathrm{C} 3 \mathrm{H} \text { type-like } 2 \text { (ZFP36L2) }^{\mathrm{a}}\end{array}$ & $\begin{array}{l}0 \\
\bullet \\
\bullet \\
\bullet \\
\bullet \\
0\end{array}$ & & $\begin{array}{l}\bullet \\
\bullet \\
\bullet \\
\bullet \\
\bullet \\
\bullet \\
\bullet\end{array}$ \\
\hline $\begin{array}{l}\text { Adenosine deaminase, RNA-specific (ADAR) } \\
\text { Complement component } 1 \text {, s subcomponent (C1S) } \\
\text { Interferon-induced protein with tetratricopeptide repeats } 1 \text { (IFIT1) } \\
\text { Interferon regulatory factor } 1 \text { (IRF1) } \\
\text { Interferon regulatory factor } 2 \text { (IRF2) } \\
\text { Mothers against decapentaplegic homolog } 4 \text { (MADH4) } \\
\text { N-myc (and STAT) interactor (NMI) } \\
\text { Plasminogen activator, urokinase receptor (PLAUR) } \\
\text { Transporter 1, ATP-binding cassette, subfamily B (TAP1) }\end{array}$ & & $\begin{array}{l}\bullet \\
\bullet \\
\bullet \\
\bullet \\
\bullet \\
\bullet \\
\bullet \\
\bullet \\
\bullet\end{array}$ & $\begin{array}{l}0 \\
\bullet \\
\bullet \\
\bullet \\
0 \\
0 \\
0 \\
0 \\
0\end{array}$ \\
\hline
\end{tabular}

TOM-RNA phosphoramidites. The luciferase siRNA oligoribonucleotides (5'-CGUACGCGGAAUACUUCGATT-3' and 5'-UC GAAGUAUUCCGCGUACGTT-3') correspond to the coding region 153-173 relative to the first nucleotide of the start codon of the Photinus pyralis luciferase gene (Elbashir et al. 2001). The nonspecific siRNA oligoribonucleotides (5'-AAUUUUUUUCCC CAAAGGGGG-3' and $5^{\prime}$-AACCCCCUUUGGGGAAAAAAA-3') were randomly synthesized and did not correspond to any known gene in the human genome database. To anneal the siRNAs, 20 $\mu \mathrm{M}$ single-stranded RNAs were incubated in annealing buffer $(100$ $\mathrm{mM}$ potassium acetate, $2 \mathrm{mM}$ magnesium acetate, $30 \mathrm{mM}$ Hepes$\mathrm{KOH}$ at $\mathrm{pH}$ 7.4) for $1 \mathrm{~min}$ at $90^{\circ} \mathrm{C}$ followed by incubation for $2 \mathrm{~h}$ at $37^{\circ} \mathrm{C}$. DsRNAs were stored at $-20^{\circ} \mathrm{C}$ until transfection.

\section{Cell culture and transfection}

HeLa S3 cells were propagated at $37^{\circ} \mathrm{C}$ in DMEM (Life Technologies) supplemented with $10 \%$ fetal bovine serum, $100 \mathrm{U} / \mathrm{mL}$ penicillin, and $100 \mu \mathrm{g} / \mathrm{mL}$ streptomycin. Cells were regularly passed to maintain exponential growth. Transfections were carried out by using Oligofectamine (Life Technologies) and $200 \mathrm{nM}$ duplex siRNA per well, as per the manufacturer's instructions. Cells were transfected one to three times at $\sim 24$-h intervals.

\section{Microarray analysis}

Total RNA was prepared from test (siRNA treated) and control (untreated) cells by using the RNeasy kit (Qiagen). Targets for hybridization to the microarrays were prepared as described (Eisen and Brown 1999). Hybridization and scanning of human U133 GeneChip Arrays (Affymetrix) were performed as recommended by the manufacturer. The complete list of genes induced or repressed by luciferase siRNA treatment is available upon request.

\section{RNA isolation and RT-PCR analysis}

RT-PCR analysis was performed according to standard protocols (Ausubel et al. 2001), except that total RNA was prepared by using the RNeasy extraction kit (Qiagen). RT-PCR products were separated by agarose gel electrophoresis and visualized by ethidium bromide staining. The density of the ethidium bromide-stained bands was quantitated by using NIH Image analysis software. Fold differences were calculated by comparing the intensity of the signal in the luciferase siRNA-treated sample relative to that obtained by using transfection reagent alone. Primer sequences used for RTPCR analysis are available upon request.

\section{ACKNOWLEDGMENTS}

We are grateful to P. Zamore for discussions during the course of this work. This work was supported by a grant to M.R.G. from the National Institutes of Health. M.R.G. is an investigator of the Howard Hughes Medical Institute.

The publication costs of this article were defrayed in part by payment of page charges. This article must therefore be hereby 
marked "advertisement" in accordance with 18 USC section 1734 solely to indicate this fact.

Received August 19, 2003; accepted September 23, 2003.

\section{REFERENCES}

Ausubel, F.M., Brent, R., Kingston, R.E., Moore, D.D., Seidman, J.G., and Struhl, K. 2001. Current protocols in molecular biology. Wiley, New York.

Bridge, A.J., Pebernard, S., Ducraux, A., Nicoulaz, A.L., and Iggo, R. 2003. Induction of an interferon response by RNAi vectors in mammalian cells. Nat. Genet. 34: 263-264.

Caplen, N.J., Parrish, S., Imani, F., Fire, A., and Morgan, R.A. 2001. Specific inhibition of gene expression by small double-stranded RNAs in invertebrate and vertebrate systems. Proc. Natl. Acad. Sci. 98: 9742-9747.

Chu, W.M., Ostertag, D., Li, Z.W., Chang, L., Chen, Y., Hu, Y., Williams, B., Perrault, J., and Karin, M. 1999. JNK2 and IKK $\beta$ are required for activating the innate response to viral infection. Immunity 11: 721-731.

Cole, K.E., Strick, C.A., Paradis, T.J., Ogborne, K.T., Loetscher, M., Gladue, R.P., Lin, W., Boyd, J.G., Moser, B., Wood, D.E., et al. 1998. Interferon-inducible $\mathrm{T}$ cell $\alpha$ chemoattractant (I-TAC): A novel non-ELR CXC chemokine with potent activity on activated $\mathrm{T}$ cells through selective high affinity binding to CXCR3. J. Exp. Med. 187: 2009-2021.

Der, S.D., Zhou, A., Williams, B.R., and Silverman, R.H. 1998. Identification of genes differentially regulated by interferon $\alpha, \beta$, or $\gamma$ using oligonucleotide arrays. Proc. Natl. Acad. Sci. 95: 1562315628.

Eisen, M.B. and Brown, P.O. 1999. DNA arrays for analysis of gene expression. Methods Enzymol. 303: 179-205.

Elbashir, S.M., Harborth, J., Lendeckel, W., Yalcin, A., Weber, K., and Tuschl, T. 2001. Duplexes of 21-nucleotide RNAs mediate RNA interference in cultured mammalian cells. Nature 411: 494-498.

Fire, A. 1999. RNA-triggered gene silencing. Trends Genet. 15: 358-363.
Geiss, G., Jin, G., Guo, J., Bumgarner, R., Katze, M.G., and Sen, G.C. 2001. A comprehensive view of regulation of gene expression by double-stranded RNA-mediated cell signaling. J. Biol. Chem. 276: 30178-30182.

Gongora, C., Degols, G., Espert, L., Hua, T.D., and Mechti, N. 2000. A unique ISRE, in the TATA-less human Isg20 promoter, confers IRF-1-mediated responsiveness to both interferon type I and type II. Nucleic Acids. Res. 28: 2333-2341.

Hannon, G.J. 2002. RNA interference. Nature 418: 244-251.

Jackson, A.L., Bartz, S.R., Schelter, J., Kobayashi, S.V., Burchard, J., Mao, M., Li, B., Cavet, G., and Linsley, P.S. 2003. Expression profiling reveals off-target gene regulation by RNAi. Nat. Biotechnol. 21: 635-637.

Kumar, A., Haque, J., Lacoste, J., Hiscott, J., and Williams, B.R. 1994. Double-stranded RNA-dependent protein kinase activates transcription factor NF-кB by phosphorylating I кB. Proc. Natl. Acad. Sci. 91: 6288-6292.

Plasterk, R.H. 2002. RNA silencing: the genome's immune system. Science 296: 1263-1265.

Schwarz, D.S., Hutvágner, G., Haley, B., and Zamore, P.D. 2002. Evidence that siRNAs function as guides, not primers, in the Drosophila and human RNAi pathways. Mol. Cell 10: 537-548.

Semizarov, D., Frost, L., Sarthy, A., Kroeger, P., Halbert, D.N., and Fesik, S.W. 2003. Specificity of short interfering RNA determined through gene expression signatures. Proc. Natl. Acad. Sci. 100: 6347-6352.

Sharp, P.A. 2001. RNA interference: 2001. Genes \& Dev. 15: 485-490.

Williams, B.R. 1999. PKR: A sentinel kinase for cellular stress. Oncogene 18: 6112-6120.

$\mathrm{Wu}, \mathrm{H} ., \mathrm{Hait}, \mathrm{W} . \mathrm{N}$., and Yang, J.M. 2003. Small interfering RNAinduced suppression of MDR1 (P-glycoprotein) restores sensitivity to multidrug-resistant cancer cells. Cancer Res. 63: 1515-1519.

Yang, Y.L., Reis, L.F., Pavlovic, J., Aguzzi, A., Schafer, R., Kumar, A., Williams, B.R., Aguet, M., and Weissmann, C. 1995. Deficient signaling in mice devoid of double-stranded RNA-dependent protein kinase. EMBO J. 14: 6095-6106.

Zamore, P.D. 2002. Ancient pathways programmed by small RNAs. Science 296: 1265-1269. 

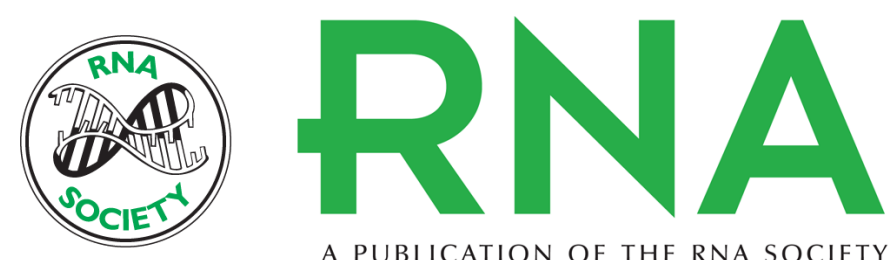

A PUBLICATION OF THE RNA SOCIETY

\section{Nonspecific, concentration-dependent stimulation and repression of mammalian gene expression by small interfering RNAs (siRNAs)}

STEPHAN P. PERSENGIEV, XIAOCHUN ZHU and MICHAEL R. GREEN

RNA 2004 10: 12-18

References This article cites 21 articles, 10 of which can be accessed free at: http://rnajournal.cshlp.org/content/10/1/12.full.html\#ref-list-1

\section{License}

Email Alerting

Receive free email alerts when new articles cite this article - sign up in the box at the Service top right corner of the article or click here.

To subscribe to $R N A$ go to:

http://rnajournal.cshlp.org/subscriptions 